\title{
DIAGNOSTIC STUDY OF BUXTONELLA SULCATA IN BUFFALOES IN MOSUL, IRAQ
}

\author{
T.M. AL-SAFFAR ${ }^{*}$, A.F. AL-TAEE**, E.D. HADI* and E.G. SULEIMAN*** \\ "Department of Internal and Preventive Medicine, ${ }^{* *}$ Department of Microbiology, Collge of Veterinary \\ Medicine University of Mosul, Mosul-Iraq.
}

\section{ABSTRACT}

Received at: 2/12/2012

Accepted: 15/1/2013
Through examination of one hundred fecal samples collected from buffaloes in different regions of Mosul city. The total percentage of infection with Buxtonella sulcata was (35\%). No significant differences were recorded between different sexes and ages of animals. Cysts of Buxtonella sulcata were diagnosed in animals with or without diarrhea but large number of cysts appeared in feces of animals suffering from diarrhea $(48.57 \%)$. Histological examination of large intestine revealed the presence of the Buxtonella sulcata associated with necrosis, hyperplasia of the intestinal epithelium, different degrees of hemorrhages, and infiltration of inflammatory cells.

Key words: Buxtonella sulcata, Buffaloes, Diagnosis

\section{INTRODUCTION}

The ciliophora which inhabits in the rumen and colon of ruminants are most considered to be commonsals participating in digestion plant feed which could be confirmed by their common incidence (Fox and Jacobs, 1986), Buxtonella sulcata is a ciliate lives in cysts form in the environment while its vegetative form lives in the colon of cattle and described as parasites (Hong and Youn, 1995). In some cases the ciliates may be responsible for incidence of diarrheal symptoms (Tomczuk et al., 2005). Buxtonella sulcata can be cause of diarrhea in calves, since the rate of diarrhea was detected higher in calves having Buxtonella sulcata cysts compared with calves without the cyst (Hong and Youn, 1995). Infection with Buxtonella sulcata follows consuming cysts with fodder or drinking water (Tomczuk et al., 2005). The increased invasion of alimentary tract of dairy cows could be resulted in clinician disorders such as poor condition (Tomczuk et al., 2005). Many authors reported different perentage of infection. In different part of the world (Arslan et al., 2001; Casemore, 1991; Henriksen, 1977; Jimenez et al., 2007 and Wakers et al., 1999). In Iraq the infection with Buxtonella sulcata recorded only in cattle in AlQadissiyha and Mosul city with percentage were 47\%, 24.16\% respectively (Aayiz, 2005 and Al-Saffar et al., 2010). Buffalos (Bubalus bubalis) in Iraq are an important economical resource for rural citizens, but in the same time received little attention of veterinary care. Little information are available about Buxtonella sulcata infection in Buffaloes in Iraq and its association with diarrheal condition in these animals. The aim of this study was to isolate Buxtonella sulcata from buffaloes with diarrheal signs and the histopathological changes it induces in these animals.

\section{MATERIALS and METHODS}

One hundred buffaloes stool samples were collected from different regions of Mosul city and from intestinal tracts of slaughter buffalos in Mosul abattoir during the period from September 2011 to June 2012 for the detection of Buxtonella sulcata in these animals. These samples were subjected to gross and microscopic examination. Gross study was aimed to evaluate stool consistency, microscopic examination include direct and concentration methods (sedimentation by tap water, $10 \%$ formalin and by using ether -formalin) (Urquhart et al., 2003; Thienpont et al., 1974; Mollan and Saaid, 1982). Morphometric characterization of the parasites (trophozoites and cyst stage was also made (Fox and Jacobs, 1986; Rommel et al., 2000 and Aayiz, 2005). Histological study of colon sections were sectioned at 4-6 $\mathrm{m \mu}$ and stained by hematoxylin and eosin stain (Luna, 1968).

\section{RESULTS}

The results of this study revealed that the percentage of the total infection with Buxtonella sulcata were $35 \%$, Trophozoites stage of the parasite were demonstrated in 4 animals (4\%) while the cysts form in 31 animals $(31 \%)$ as shown in table (1).

Males of buffaloes show high percentage of infection $(40 \%)$ than the female $(30 \%)$, statistical analysis showed that no significant differences appeared 
between males and females Table (2). The group of animal aged 2-3years showed the highest rate of infection (63.63\%) among all infected animals and the lowest rate at the age group 3years-and more and there was no significant differences appeared between all ages of animals.

The correlation between Buxtonella sulcata infection and consistency of faeces (diarrheal or normal) presented in table (4), from this table it was indicated that most of the infected animals (48.57\%) were diarrheic while in normal feces animal (27.69\%) statistically analysis showed no significant differences between diarrheic and non diarrheic animals. Table (5) gives various intensity of infection according to the number of cysts in examined microscopic field, the highest rate of intensity in severe infection (5 cyst and more) were $47.5 \%$ in diarrheic animal and the low infection (one cyst) were $(22.22 \%)$ in normal feces animals and there was significant differences appeared in intensity of infection in animals without diarrhea.
The morphological study and main characteristic features of the parasites were shown in Fig. 1,2 that the parasites appear with cyst form usually circular and varying in sizes from $60-68.6 \times 60-68.8 \mathrm{~m} \mu$ and the average $(62.09 \mathrm{~m} \mu)$ while the trophozoites usually ovoid shape and varying in size from about (84$127.4 \times 68.6-84 \mathrm{~m} \mu)$, surrounded by cilia and containing central nucleus with cytostom in the anterior end and a number of nutrition vacuoles in the cytoplasm. Histopathological changes accompanied with the Buxotanella sulcata infection was characterized by the presence of trophozoites and cysts in the lumen of the colon (Fig 3,4). Mucoid epithelium degeneration, necrotic sloughing of the intestinal epithelium and submucosal glands with sever hyperplasia of the intestinal mucosa, inflammatory cells infiltration and mild haemorrhage were observed (Fig 5,6,7). Hyperplasia, elongation, necrosis and sloughing of the villi with sever mucosal and submucosal inflammatory cells infiltration $(8,9)$.

Table 1: Percentage of Buxtonella sulcata infected buffaloes

\begin{tabular}{cccc}
\hline $\begin{array}{c}\text { No. of examined } \\
\text { samples }\end{array}$ & $\begin{array}{c}\text { No. of positive (cyst } \\
\text { form) } \%\end{array}$ & $\begin{array}{c}\text { No. of positive } \\
\text { (trophozoites) } \%\end{array}$ & Total percentage \\
\hline 100 & $31(31 \%)$ & $4(4 \%)$ & $35 \%$ \\
\hline
\end{tabular}

Table 2: Percentage of Buxtonella sulcata infection in buffalo in relation to their sex

\begin{tabular}{cccc}
\hline Sex of animal & No. examined & No .infected & Percentage \\
\hline Female & 50 & 15 & 30 \\
\hline Male & 50 & 20 & 40 \\
\hline Total & 100 & 35 & 35 \\
\hline
\end{tabular}

No significant differences between males and females $(\mathrm{p}>0.05)$

Table 3: Percentage of Buxtonella sulcata infection in buffalo in relation to their age

\begin{tabular}{cccc}
\hline Age group & No .examined & No .infected & Percentage \\
\hline Less than 1-year & 35 & 15 & 42.85 \\
\hline 1-2 year & 11 & 3 & 27.27 \\
\hline 2-3 year & 11 & 7 & 63.63 \\
\hline 3- and more & 43 & 10 & 25.25 \\
\hline total & 100 & 35 & 35 \\
\hline
\end{tabular}

No significant association between percentage of infection and ages 


\section{Assiut Vet. Med. J. Vol. 59 No. 136 January 2013}

Table 4: Percentage of buffalo infected with Buxtonella sulcata with or without diarrhea

\begin{tabular}{cccc}
\hline Group of animal & No .examined & No .positive & Percentage \\
\hline Animal with diarrhea & 35 & 17 & 48.57 \\
\hline Animals without diarrhea & 65 & 18 & 27.69 \\
\hline Total & 100 & 35 & 35 \\
\hline
\end{tabular}

No significant differences between animal with and without diarrhea

Table 5: Infection intensity with Buxtonella sulcata in buffaloes

\begin{tabular}{ccccc}
\hline Group of animals & $\begin{array}{c}\text { Low infection * } \\
\text { No.of positive }(\%)\end{array}$ & $\begin{array}{c}\text { Moderate infection*** } \\
\text { No. of positive }(\%)\end{array}$ & $\begin{array}{c}\text { High infection *** } \\
\text { No.of positive }(\%)\end{array}$ & Total \\
\hline Animals with diarrhea & $5(29.4) \mathrm{a}$ & $4(23.5) \mathrm{a}$ & $8(47.5) \mathrm{a}$ & $17(48.6)$ \\
\hline Animal without diarrhea & $14(77.8) \mathrm{a}$ & $4(22.2) \mathrm{b}$ & $0(0) \mathrm{b}$ & $18(27.7)$ \\
\hline Total & $19(54.28)$ & $8(22.85)$ & $8(22.85)$ & $35(35)$ \\
\hline
\end{tabular}

$\mathrm{a}, \mathrm{b}$ different letters in each raw refer to significant variation $(\mathrm{P}<0.05)$

* Low infection 1cystlHPMF

**Moderate infection 2-4cysts \HPMF

*** High infection 5 cyst and more $\backslash \mathrm{HPMF}$

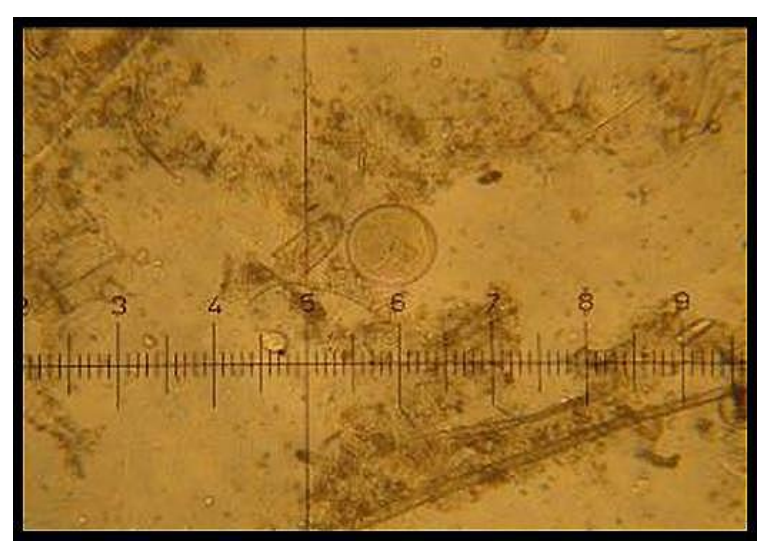

Fig 1: Cyst of Buxtonella sulcata in feces of buffalo ,40X, by using digital camera

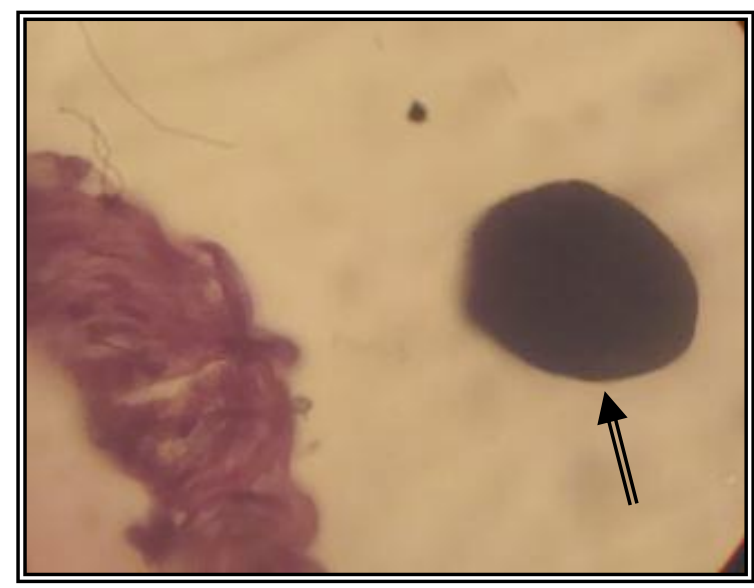

Fig 3: Presence of trophozoites at the lumen of colon H\&E, $100 X$

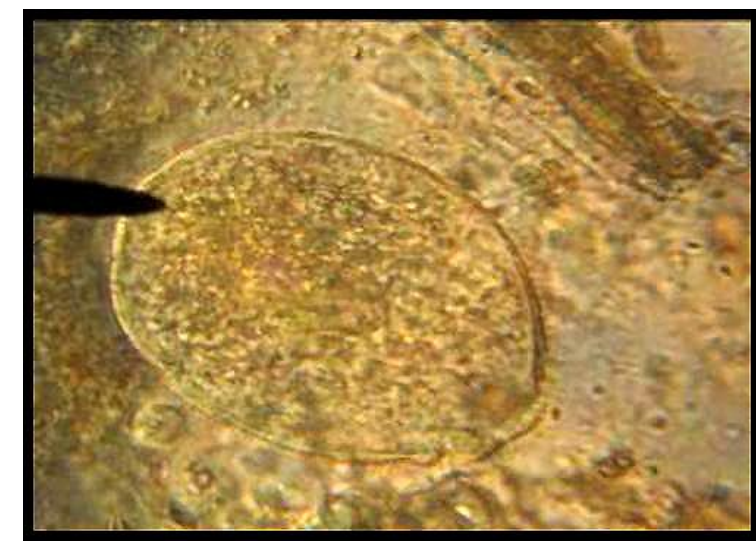

Fig 2: Trophozoites of Buxtonella sulcata in feces of buffalo, $760 \mathrm{X}$, by using digital camera

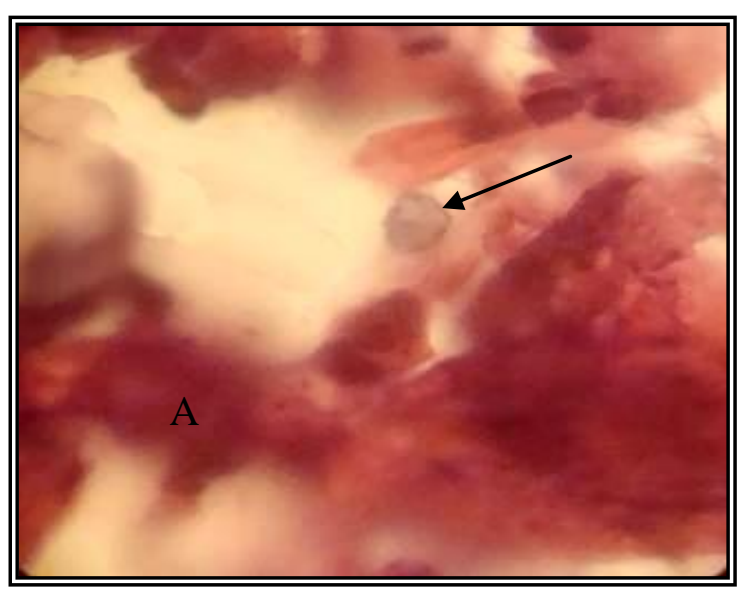

Fig 4: Presence of the cyst of Buxtonella sulcata in the lumen of the colon with slaughing of necrotic intestinal epithelium (A) $\mathrm{H} \& \mathrm{E}, 145 \mathrm{X}$ 


\section{Assiut Vet. Med. J. Vol. 59 No. 136 January 2013}

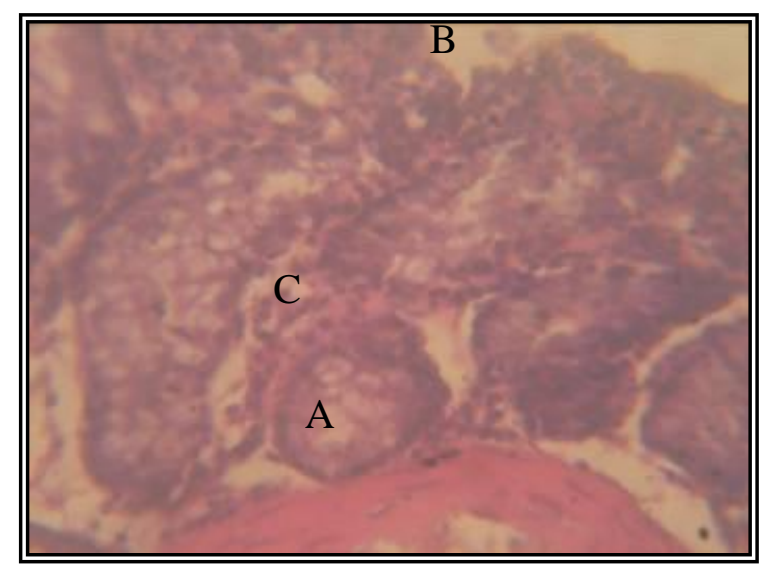

Fig 5: Presence mucoid degeneration(A) with sloughing of the intestinal epithelium(B) with mild infiltration with neutrophiles(C), $\mathrm{H} \& \mathrm{E}, 165 \mathrm{X}$

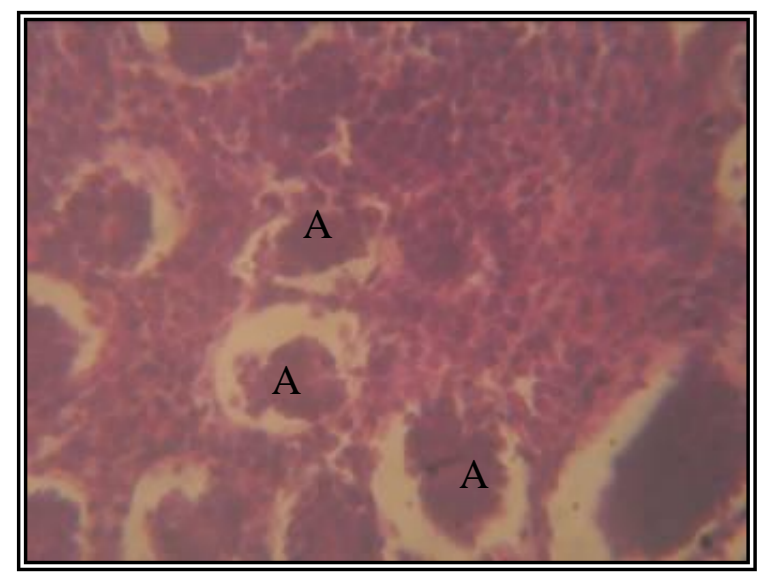

Fig 7: Degeneration and necrosis, slaughing of the epithelial of submucosal glands(A) H\&E, 165X

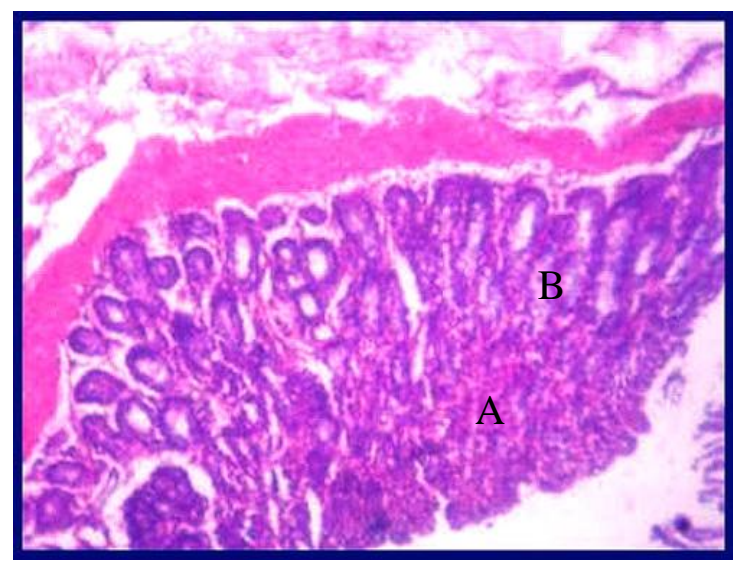

Fig 6: Epithelial hyperplasia of intestinal mucosa (A)with presence mucoid degeneration(B) ,inflammatory cells infiltration and mild hemorrhage (B) H\&E, 145X

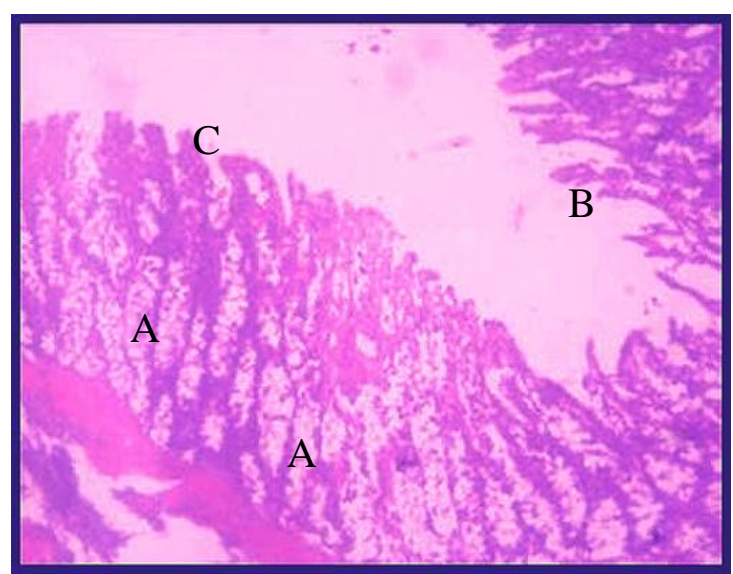

Fig 8: Mucoid degeneration(A), necrosis and slaughing of the intestinal epithelial(B), hyperplasia and elongation of the villi $(\mathrm{C})$ $\mathrm{H} \& \mathrm{E}, 165 \mathrm{X}$

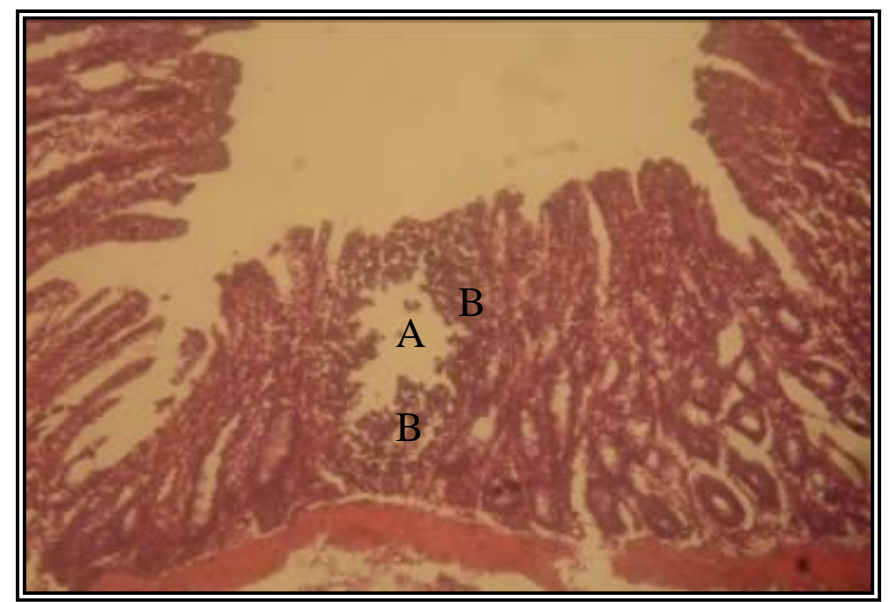

Fig 9: Necrosis and sloughing of the villi(A) with sever inflammatory cells infiltration (B)H\&E, 165X 


\section{DISCUSSION}

The protozoan parasites living in gastrointestinal tract of agricultural animals participate in symbiotic digestion of food stuffs with their hosts. (Tomczuk et al., 2005). Any change in the microenvironment of the gastrointestinal tract may predispose to the change in the living manner of these parasites to those that secret digestive enzymes, thereby negatively affecting the intestinal epithelium of the host. Buxtonella sulcata is one example for this conversion upon microenvironment change in the host gastrointestinal tract. Colon infection of this protozoan parasites in buffaloes resemble that of Balantidiasis and Entamebiasis in ruminants (Rommel et al., 2000; Skokotarczak, 1997 and AlKennany et al., 2009), causing diarrhoea, inflammation and ulcerative lesions. Our results of the samples gathered from buffaloes with or without diarrhoea, showed that the total percentage of infection was $35 \%$ with trophozoites (4\%), and cysts $(31 \%)$. When we compared our results with others, it appeared that our results were more than that reported in Banklaore in cattle of (17\%); those found by (Mamatha and Souza, 2006) of $(12.6 \%)$ and $(20.5 \%)$ for cattle and buffaloes respectively; in Turkey with $(9,5 \%)$ in calves (Altug et al., 2006), those reported here in Mosul province by (Al-Saffar et al., 2010) of $(24.1 \%)$. In the other hand our results were less than those reported by (Aayiz, 2005) in cattle in AlQadissiyha province with cyst (47\%) and infection of $71.8 \%$ in Danish cattle (Henriksen, 1977) while the prevalence which reported in Germany has been range from zero-73\% (Wakers et al., 1999). In this study many factors appeared to affect the percentage of infection with this protozoan parasite like age, since animals aged 2-3 years had the highest rate of infection of $63.63 \%$ over the rest of the studied ages. It could be said that progress in age may add immunity to the animals against the parasites (Urquhart et al., 2003). Another factor is the health status, especially with those suffered from diarrhoea having a significant higher percentage of infection and being $48.57 \%$, compared with non-diarrhoeal animals with infection of $27.69 \%$ (Tomczuk et al., 2005; Altug et al., 2006; Al-Saffar et al., 2010 and Aayiz, 2005). A third relationship was recorded to the favour of cysts number and intensity of infection (Tomczuk et al., 2005 and Al-Saffar et al., 2010). It should be stressed that gender has no effect on the percentage of infection with Buxtonella sulcata. Our results were in agreement with the line of (Tomczuk et al., 2005), who revealed that this protozoan parasite infection could results in GIT damage, which correlated with the virulence of parasite, host susceptibility, sensitivity to infection, microenvironment of the parasite, location in the GIT, and the secondary bacterial infection. Another study referred to what mentioned above and stressed on the change of the parasite microenvironment in the GIT especially $\mathrm{pH}$ changes. Parasite infection is usually results in profound damage in the GIT, lining leading to inflammatory process, as it is evident in the histopathological sections in colon (Urman and Kelly, 1968).

\section{REFERENCES}

Aayiz, N.N. (2005): Diagnostic study for cow infection with Buxtonella sulcata in Iraq. AlQadissiyha J. Vet. Sci., 4(2): 53-56.

Al-Kennany, E.R.; Yahya, D.M. and Abd-Allua, A.N. (2009): Pathological and histochemical study in the large intestine experimentally infected with Entamoeba histolytica in mice. An. J. Vet. Sci., 2(2): 87-95.

Al-Saffar, T.M.; Suleiman, E.G. and Al-Bakri, H.S. (2010): Prevalence of intestinal ciliate Buxtonclla sulcata in cattle in Mosul, Iraqi. J. Vet. Sci., 24(1): 27-30.

Altug, M.N.; Yuksek, N. and Ozkan, C. (2006): Parasites defected in neonatal and young calves with diarrhea, Bull. Vet. Inst. Pulawy, 50: 345-348.

Arslan, M.O.; Gicik, Y.; Erdogan, H.M. and Sari, B. (2001): Prevalence of Cryptosporidium spp.oocysts in diarrhoeal calves in kars province, Turkey. Turk. J. Vet. Anim. Sci., 25: 161-164.

Casemore, D.P. (1991): Laboratory methods for diagnosing cryptosporidiosis. J. Clin. Path., 44: 445-451.

Fox, M.T. and Jacobs, D.E. (1986): Patterns of infection with Buxtonella sulcata in British cattle. Res. Vet. Sci., 41: 90-92.

Hang, K.O.; Youn, H.J. (1995): Incidence of Buxtonella sulcata from cattle in Kyonggi-do. Korean. Parasitol., 33: 135-138.

Henriksen, S.A. (1977): Buxtonella sulcata an intestinal ciliate of apparently frequence occurrence in Danish cattle. Nord. Vet. Med., 29(10): 452-7.

Jimencz, A.E.; Montenegro, V.M.; Hernandez, J.; Dolz, G.; Maranda, L.; Galindo, J.; Epe, C. and Schineder, T. (2007): Dynamics of infection with gastrointestinal parasites and Dictyocaulus viviparous in dairy and beef cattle from Costa Rica. Vet. Parasitol., 148: 262-271.

Luna, L.G. (1968): Manual of histological staining methods of the armed forces institute of pathology $3^{\text {rd }}$. ed., New York, McGraw Hill book Company, 38-76.

Mamatho, G.S. and Souza, E.D. (2006): Gastrointestinal parasitism of cattle and buffaloes in and around Bangalore. J. Vet. Parasitol., 20(2): $1-2$.

Mollan, A.A. and Saaid, E.S. (1982): Principles of manual parasitology. University of Mosul, 308P.

Rommel, M.; Eckert, J.; Kutzer, E.; Korting, W. and Schneider, T. (2000): Veterinar medizinische Parasitologie. Parey Buchverlag, Berlin[cited Tomczuk et al., 2005.

Skotarczak, B. (1997): Bacterial folora in acute and symptom-free balantidiosis. Acta. Parasitol., 42: $230-233$. 
Thienpont, D.; Rochette, F. and Janparjs, O.F.J. (1974): Diagnostic helminthiasis through coprological examination. Beerse Belgium. 34-36P.

Tomczuk, K.; Kurck, L.; Stec, A.; Studzinska, M. and Mochol, J. (2005): Incidence and clinical aspects of colon ciliate Buxtonella sulcata infection in cattle. Bull. Vet. Inst. Pulawy, 49: 29-33.

Urman, H.D. and Kelly, G.O. (1964): Buxtonella sulcata. Aciliate associated with ulcerative colitis in a cow and prevalence of infection in
Nebraska cattle. Low state Univ. Vet., 27: 118-122.

Urquhart, G.M.; Armour, J.; Duncan, J.I.; Dunn, A.M. and Jennings, F.W. (2003): Veterinary parasitology. $2^{\text {nd }}$ ed., Black well Science Ltd., Oxford: 263-276P.

Wackers, K.; Roffeis, M. and Conraths, F.J. (1999): Cow-calf herds in eastern Germany: status Que of some parasite species and a comparison of chemoprophylaxis and pasture management in the control of gastrointestinal nematodes. J. Vet. Med., 46(7): 475-483.

\footnotetext{
دراسة تثخيصية لطقيلي Buxtonella sulcata في الجاموس في الموصل/العراق

طلال محمود الصفار ، احلام فتحي الطائسي ، ابيان دحام هادي ، ابيان غانم سليمان

تبين من خلال فحص 100 عينة بر از جمعت من الجاموس وذللك من مناطق مختلفة في مدينة الموصل أن نسبة الإصابة الكلية بطفيلي Buxtonella sulcata

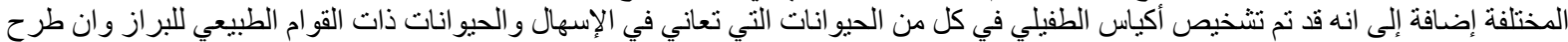

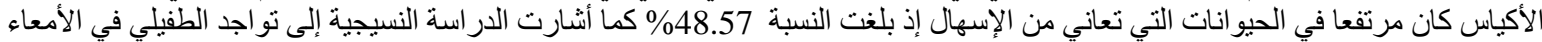

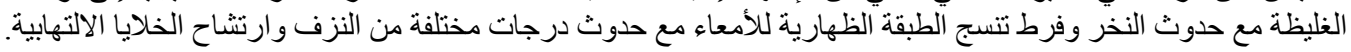

